\title{
Nanosecond Pulsed Electric Fields (nsPEFs) Induce Socs1 and Socs3 but not Socs2 Gene Expressions in Hela S3 Cells
}

\section{Nanosecond Pulsed Electric Fields (nsPEFs) Menginduksi Ekspresi Gen Socs1 dan Socs3 namun bukan Socs2 pada Sel HeLa S3}

\author{
Martina Kurnia $R^{1}$, Diana Lyrawati ${ }^{2}$, Kenichi Yano ${ }^{3}$ \\ ${ }^{1}$ Master in Biomedical Science Faculty of Medicine University of Brawijaya Indonesia \\ ${ }^{2}$ Departement of Pharmacology Faculty of Medicine University of Brawijaya Indonesia \\ ${ }^{3}$ Bioelectric Laboratory Institute of Pulse Power Science Kumamoto University Japan
}

\begin{abstract}
Nanosecond Pulsed Electric Fields (nsPEFs) is one of bioelectric technologies applied widely in a number of sciences. nsPEFs cause some biological responses and known to play a role as a novel cancer therapy. However, the nsPEFs molecular mechanisms have not been fully elucidated. This study determines the effects of nsPEFs in socs (Suppressor of Cytokine Signaling) genes which are target genes of JAK/STAT signaling pathway. Through a negative feedback mechanism, SOCS proteins can suppress both cytokine signal transduction and overgrowth factor, so the cell growth is controlled. In cervix cancer, the presence of E6 and E7 HPV's oncoprotein is associated with methylation and inactivation of socs 1 and socs 3 genes. This mechanism is related to the increase of STAT expression and cancer prognostic. In this research, nsPEFs as much as $20 \mathrm{kV} / \mathrm{cm}$ for $80 \mathrm{~ns}$ was exposed over HeLa S3 cells in $4 \mathrm{~mm}$ cuvette. Socs1, socs 2 and socs 3 gene expressions were analyzed using real time PCR SYBR green and reverse transcription PCR (RT-PCR). This study shows that at 20 and 30 shots, nsPEFs significantly increase socs 1 and socs3 but not socs 2 gene expression. Effect of nsPEFs on socs 1 and socs 3 gene expression pattern is influenced by duration of post exposure incubation and each cell activity on internal cell condition. This research provides a new cancer therapy target for nSPEFs.
\end{abstract}

Keywords: Bioelectric, gene expression, nSPEFs, shot, socs gene

\begin{abstract}
ABSTRAK
Nanosecond Pulsed Electric Fields (nsPEFs) merupakan salah satu teknologi bioelektrik yang secara luas diaplikasikan pada sejumlah bidang sains. NsPEFs dapat menyebabkan sejumlah respon biologis dan diketahui berperan sebagai salah satu novel terapi kanker. Meski demikian, mekanisme molekular nsPEFs belum banyak diketahui. Penelitian ini bertujuan untuk mengetahui efek nsPEFs pada gen socs (Suppressor of Cytokine Signaling) yang merupakan salah satu gen target jalur sinyal JAK/STAT. Melalui aktivitas umpan balik negative, protein SOCS dapat menekan transduksi sinyal sitokin dan faktor pertumbuhan yang berlebih sehingga dapat mengontrol pertumbuhan sel. Pada kanker serviks, kehadiran onkoprotein HPV E6 dan E7 diasosiasikan dengan metilasi dan inaktivasi gen socs1 dan socs3. Mekanisme tersebut juga berkaitan dengan peningkatan ekspresi STAT dan peningkatan prognosivitas kanker. Pada penelitian ini, nsPEFs sebesar $20 \mathrm{kV} / \mathrm{cm}$ selama $80 \mathrm{~ns}$ dipaparkan pada sel HeLa S3 di dalam kuvet $4 \mathrm{~mm}$. Ekspresi gen socs1, socs2 dan socs3 dianalisis menggunakan real time PCR SYBR green dan reverse transcription PCR (RT-PCR). Penelitian ini menunjukkan bahwa pada 20 dan 30 kali tembakan, nsPEFs mampu meningkatkan ekspresi gen socs 1 dan socs3, namun bukan socs 2 . Efek nsPEFs pada kedua gen tersebut juga dipengaruhi lamanya waktu inkubasi pasca paparan dan aktivitas masing-masing gen pada kondisi internal sel. Penelitian ini memberikan target terapi kanker baru bagi nsPEFs.
\end{abstract}

Kata Kunci: Bioelektrik, ekspresi gen, gen socs, nsPEFs, tembakan

Jurnal Kedokteran Brawijaya, Vol. 28, No. 3, Februari 2015; Korespondensi: Martina Kurnia R. Master Student of Biomedical Science Faculty of Medicine University of Brawijaya Indonesia, Jl. Veteran Malang Indonesia Phone. (0341) 569117 Email: martina.kurniarohmah@gmail.com 


\section{INTRODUCTION}

Nanosecond pulsed electric fields (nsPEFs) are one of bioelectric application that developed from conventional electroporations. Generally, electroporations are used to deliver plasmid, gene, antibody or other molecules to cell for some purposes especially for therapy (1).Unlike electroporations, nsPEFs are exposurewith high electric fields $(1-100 \mathrm{kV} / \mathrm{cm})$ in very short duration (1-300 nanoseconds). It causes low energy density and non thermal effect (2). In cell membrane, nsPEFs cause nanoporeformation $(1-1,5 \mathrm{~nm})$ without disturb the membrane integrity (3). NsPEFs also activate voltagegated $\mathrm{Ca}^{2+}$ channels and increases $\mathrm{Ca}^{2+}$ influx into cytoplasm (4).

Unlike conventional electroporations, nsPEFs raise some intracellular responses. In the high intensity, nsPEFs reach subcellular level and can be active in cellular system (5). In mitochondria, nsPEFs increase mitochondrial membrane permeability (mPTP) andcause cytochrome c release $(6,7)$. NsPEFs also cause $\mathrm{Ca}^{2+}$ influx into mitochondria and induce dissipation of membrane potential $\left(\Delta \Psi_{\mathrm{m}}\right)$ that implicate to cell viability $(7,8)$. NsPEFs also cause $\mathrm{Ca}^{2+}$ release from ER (9), involve in some signaling pathways (10-12), and induce stress responses (13). In the nucleus, nsPEFs increase some endogen gene expressions (14). In the high intensity $(>60 \mathrm{kV} / \mathrm{cm})$, nsPEFs can cause actin filament depolymerization, disturb telomere attachment to the nucleus and disturb DNA stability (15).

Recently, application of electric fields in an extremly short duration with high intensity is widely used in various fields of the life science including for cancer therapy. NsPEFs can induce apoptosis via intrinsic and extrinsic pathways (1618). NsPEFs also decrease cell proliferation and metastasis via suppression of NFKB and Wnt/ $\beta$-catenin signaling (12), decrease viability of cancer cell (19), decrease tumor mass and size $(12)(20)$, haveantiangiogenic activity $(21,22)$ and increase the immune system (23).

Suppressor of Cytokine Signaling (SOCS) proteins areidentified as tumor suppressor proteins andone of the cancer targeted therapies. In normal condition, the active SOCS have important role in negative feedback mechanism of JAK/STAT signaling pathway and inhibit cytokine and growth factor signal transduction (24). In some cancers, overexpressions and dysregulations of JAK/STAT signaling pathway are associated with high proliferation and low apoptosis. However, SOCS are methylated and silenced in many cancers (25-32). Dysregulations of SOCS are also associated with phosphorylation defect and mutation $(33,34)$. SOCS1, SOCS2 and SOCS3 are reported as the three most active SOCS protein with some tumor suppression roles.

Cervical cancer is one of gynecological cancer that caused by HPV infection. Two oncoproteins of HPV, E6 and E7, can trigger carcinogenesis and genetic instability (35). The presences of HPV's genomes are associated with overexpression of STAT3 and STAT5, and are also implicateto prognosivity of cancer $(36,37)$. STAT3 and STAT5 overexpressions are also assoaciated with epigenetic control as well as methylation at promoter of socs1 gene (38). E6 and E7 can induce methylation in some tumor suppressor genes including socs1 and socs3 (39). Wherease, the activity of socs 2 has not found in cervical cancer. However, the overexpression of STAT3 and STAT5 as the degradation target of socs 2 is one reason to investigate socs 2 gene expression (40).

The role and molecular mechanisms of nsPEFs in cancer have not been fully elucidated. In this research, we will investigate the effect of nsPEFs on socs 1 , socs 2 and socs 3 gene expressions. This research will provide a new possibility role of nsPEFs on cancer therapy.

\section{METHOD}

\section{Cell Culture and Sample Preparation}

HeLa S3 cells (ATCC) were cultured in $\alpha$-minimum essential medium ( $\alpha$-MEM)(WAKO) supplemented with $10 \%$ fetal bovine serum (FBS) (Equitech Bio) and penicillin/streptomycin (WAKO). Cells were maintained in a humidified atmosphere of $5 \% \mathrm{CO}_{2}$ at $37^{\circ} \mathrm{C}$. The cells were counted using cell counter coulter Z.1. The $2 \times 10^{6}$ cell nsPEFs cells were suspended in $400 \mu \mathrm{l} \alpha$-MEM-10\%FBS lacking antibiotics.

\section{Application of NsPEFs}

The cell suspensions $(400 \mu \mathrm{l})$ were placed in an electroporation cuvette that contained a pair of parallel aluminium electrodes with a $4 \mathrm{~mm}$-gap (\#5540, MßP, Thermo Fisher Scientific). A train of nsPEFs was generated by a pulsed power modulator and applied to the cell suspensions in the cuvette at $1 \mathrm{~Hz}$. Voltage waveform of electric pulses were monitored by a high-voltage probe (P6015A, Tektronix) in the oscilloscope. NsPEFs were exposured at $20 \mathrm{kV} / \mathrm{cm}$ with pulses of $80 \mathrm{~ns}$ duration (was standarderized in Bioelectric Laboratory, Institute of Pulse Power Science, Kumamoto University, Japan). After exposure, the cells were immediately diluted 4-folds aMEM-10\%FBS lacking antibiotics and incubated in $5 \% \mathrm{CO}_{2}$ incubator at $37^{\circ} \mathrm{C}$ during 1 and 4 hours (hr).

\section{RNA Isolation}

Total RNA was isolated from all samples using RNAiso Plus reagent (Takara Bio). Aliquots of the total RNA were subjected to real time PCR SYBR Green and RT-PCR. The total RNA concentration and purity were confirmed using Biophotometer plus (eppendorf).

\section{Real Time PCR Analysis}

Quantitative mRNA analysis was conducted by quantative real time PCR using iScript One-Step RT-PCR kit with SYBR Green (Biorad) on an MJ Mini Thermal Cycler equipped with a Mini Opticon Real Time PCR system (BioRad). Real time PCR data were calculated by measuring the average cycle threshold (Ct) number for the mRNA of target, which was normalized to the values of the mRNA for glyceraldehydes-3-phosphate dehydrogenase (GAPDH).

\section{Reverse Transcription PCR (RT-PCR)}

Semiquantitative mRNA analysis was conducted by RT-PCR using OneStep RT-PCR Kit (Qiagen) on RT-PCR system. PCR products were separated by agarose gel electrophoresis and visualized by UV transluminator. Intensity of band was quantified by ImageJ software.

\section{Primer Optimization}

The primer pairs for each gene (socs 1 , socs 2 and $\operatorname{socs} 3$ ) that used in this research were optimized based on primer dimmer presence and consistency of melt curve in the real time PCR (Supplementary data). The primer pairsthat used as the result from the optimizationof the methods as follows (32)(10), socs 1 (202 bp), F: 5'A G A C C C C T T C T C A C C T C T T G - $3^{\prime}$; R: $5^{\prime}$ CTGCACAGCAGAAAAATAAAGC-3'; socs2 (244 bp), F: 5'G GATGGTACTGGGGAAGTATGACTG - 3 '; R: 5 ' AGTCGATCAGATGAACCACACTGTC-3'; socs3 (107 bp), F: 5'- 


\section{A. Socs1}

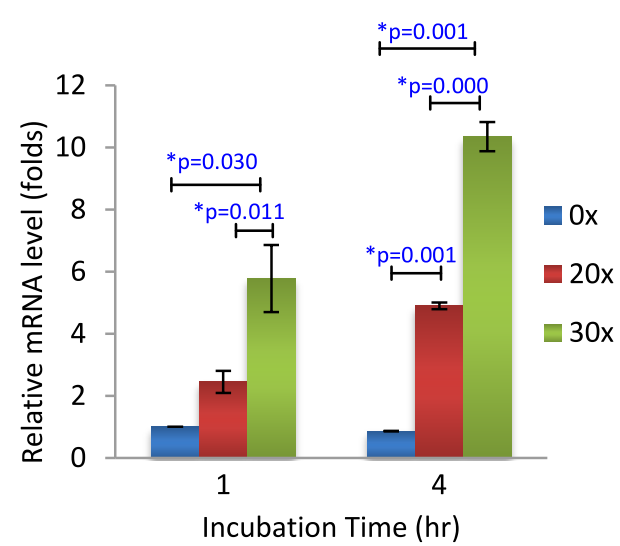

\section{Socs3}

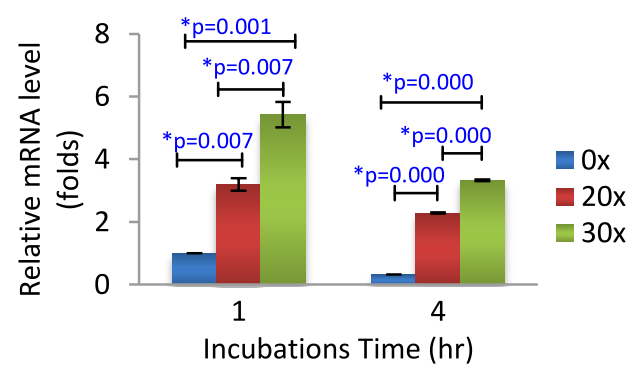

B. Socs2
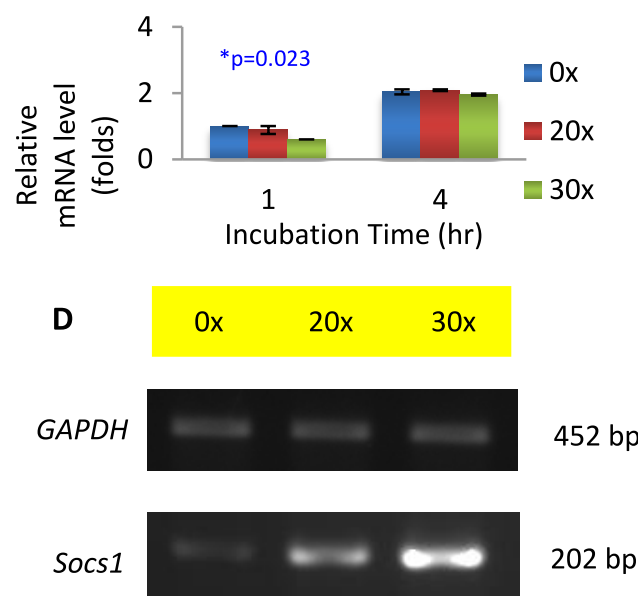

Socs 2

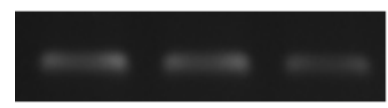

$244 \mathrm{bp}$

Socs3

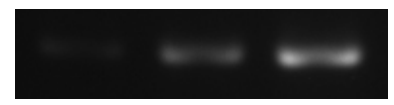

$107 \mathrm{bp}$

Figure 1. Effect of NsPEFs on Socs gene expressions

Note: A) Socs 1 , the 20 and 30 shots nsPEFs significantly increased socs 1 gene expression at 1 and 4 hr; B) Socs2, the 20 and 30 shots NsPEFs significantly increased socs 2 gene expression at $1 \mathrm{hr}$ but not at $4 \mathrm{hr}$; C) Socs3, the 20 and 30 shots nsPEFs significantly increased socs 3 gene expression at 1 and 4 hr; D) RT-PCR data.

TCCCCCCAGA A A G C C TATTAC- $3^{\prime} ; \mathrm{R}: 5{ }^{\prime}$ TCCGACAGAGATGCTGAAGAGTG-3'; GAPDH (452bp), F: 5 ' - ACCACA TCCATG CCATCAC - $3^{\prime}$, R: $5^{\prime}$ TCCACCACCCTGTTGCTGTA-3'.

\section{Statistical Analysis}

The present data were expressed as mean \pm SD. The distribution of data was evaluated using KolmogorovSmirnov analysis. The data were analyzed using one way analysis of variance (ANOVA) with HSD Tukey post hoc test, simple t-test, and correlation-regression test. Statistic significance was set at $P$ value $<0,05$.

\section{RESULTS}

NsPEFs IncreasedSocs1 and Socs3 but not Socs2 Gene Expressions

Previous study reported that $20 \mathrm{kV} / \mathrm{cm}$ during $80 \mathrm{~ns}$ duration at 20 and 30 shots treated into HeLa S3 cell decreased $15 \%$ and $30 \%$ cell viability and cell growth (41). Our results showed that these numbers of nsPEFs increased socs 1 (Figure 1A) and socs3 (Figure 1C) but not socs2 (Figure 1B) gene expressions.

Based on the one way ANOVA, we suggest that nSPEFs significantly increased socs 1 and socs 3 but not socs 2 gene expressions. At $1 \mathrm{hr}, 20$ and 30 shots nsPEFs increased socs 1 geneexpression approximately 2,45 and 5,78 folds. Socs 1 gene expression increased up to 4,90 and 10,34 folds at $4 \mathrm{hr}$. NsPEFs also increased socs 3 gene expression. At $1 \mathrm{hr}, 20$ and 30 shots nsPEFs increased socs 3 gene expressions approximately 3,19 and 5,42 folds. At 4 hr, 20 and 30 shots nsPEFs increased socs 3 gene expression approximately 2,28 and 3,33 folds. NsPEFs did not increasesocs 2 gene expression.

Effect of nsPEFs on socs1, socs 2 and socs 3 gen expressions at $1 \mathrm{hr}$ and $4 \mathrm{hr}$ were observed using different analysis respectively using real time PCR and RT-PCR. Based on the simple t-test, the expression of socs 1 , socs 2 and socs 3 were significantly different between at $1 \mathrm{hr}$ and $4 \mathrm{hr}$ in 0 , 20 , and 30 shots nsPEFs respectively socs $1(p<0,000$; $p<0,014, p<0,010)$, socs $2(p<0,015 ; p<0,024 ; p<0,047)$, and $\operatorname{socs} 3(p<0,044 ; p<0,002 ; p<0,006)$.

Shot Number of NsPEFs Correlated with Socs1 and Socs3 but not Socs2 Gene Expressions

Based on the correlation-regression analysis, we suggest that different shot number of nsPEFs correlated with socs 1 and socs 3 but not socs 2 gene expressions as we show at the Figure 2.

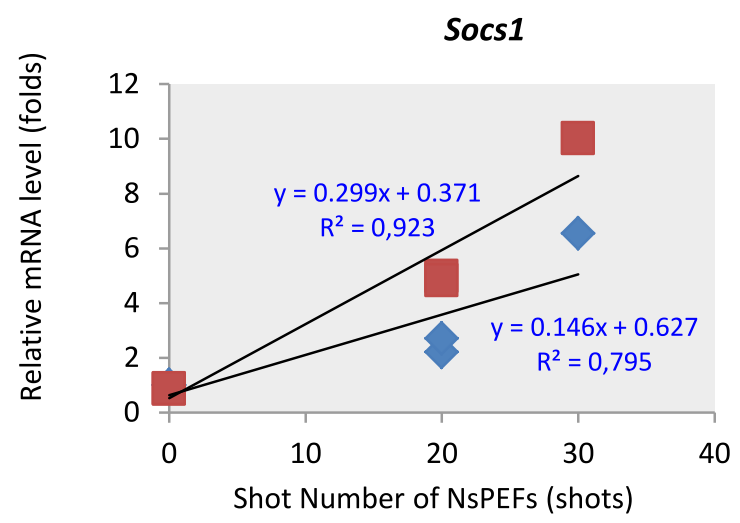

Figure 2. Correlations between shot number of NsPEFs with Socs 1 , Socs 2 and Socs 3 gene expressions

Note: The correlation between shot number and socs 1 and socs 3 gene expressions were indicated with positive correlation, but negative correlation for socs 2 . ——1 jam; - -4 jam; 


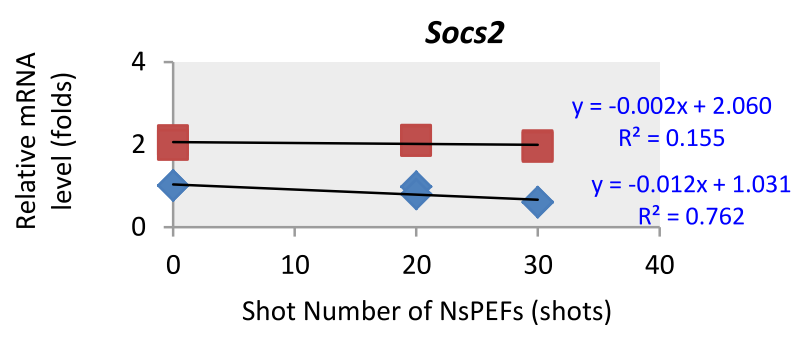

Socs3

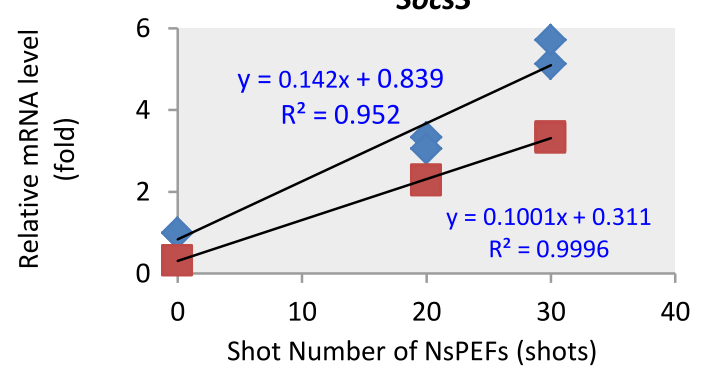

Figure 2. Correlations between shot number of NsPEFs with Socs 1 , Socs 2 and Socs 3 gene expressions

Note: The correlation between shot number and socs 1 and socs 3 gene expressions were indicated with positive correlation, but negative correlation for socs2. $-1 \mathrm{jam} ;-\square$ - jam;

\section{Different Pattern of Socs1 and Socs3 Gene Expressions} Followed NsPEFs

Gene expression pattern was determined to know the dynamic of nsPEFs effect on socs1, socs2, and socs3 gene expressions during a certain time (see Figure 3 ). Gene expression pattern of socs 1 due to 20 and 30 shots nsPEFs increased from $1 \mathrm{hr}$ to $4 \mathrm{hrs}$. In contrary, the control group was decreased during $4 \mathrm{hrs}$. Unlike socs 1 , socs3 gene expression initially increased at $1 \mathrm{hr}$ but subsequently decreased after $1 \mathrm{hr}$ up to $4 \mathrm{hr}$. The pattern of control group of socs3 decreased too, but still lower than treatment group. Gene expression pattern of socs2 in control group and treatment group increased, but these expressions were not significantly different. These data showed that nsPEFs resulted in changes gene expressions pattern in socs 1 and socs 3 , but not in socs 2 .

\section{DISCUSSION}

NsPEFs Probably Decrease Proliferation and Induce Apoptosis via Increasing of Socs1 and Socs3 Gene Expressions

In the cervical cancer, HPV infections cause socs 1 and socs 3 methylations $(36,37,39)$. These methylations implicate to STAT3 and 5 overexpressions (38). Generally, methylation of socs 1 and socs 3 implicate to high proliferation and low apoptosis in some cancers (36-39). Wherease, the rolesof socs 2 have not been known in this cancer. Our results show that 20 and 30 shots of $20 \mathrm{kV} / \mathrm{cm}$ nsPEFs in 80 ns duration increased socs 1 and socs 3 but not socs 2 gene expressions. From the control group of our results indicate that there were not any changes on socs 2 gene expressions.

Socs 1 , socs 2 and socs 3 are involved in negative feedback mechanism of JAK/STAT signaling pathway (41). By this mechanism, increasing of socs1, socs2, socs3 decrease JAK/STAT target genes that regulate cell proliferation and apoptosis, such as $c-m y c$ and $b c l-x l$ (24). According to these theories, we propose that nsPEFs may decrease proliferation and induce apoptosis via increasing of socs 1 and socs 3 gene expressions. Inducing socs 1 and socs 3 gene expressions by nsPEF probably decrease JAK/STAT signal transduction and implicate to decreasing of $c-m y c$ and $b c /$ $x l$. Decreasing of $c-m y c$ (induce proliferation) and anti apoptotic $b c|-x|$ can decrease cell proliferation and induce apoptosis. Increasing of socs 1 by nsPEFs probably causes decreasing of $c-m y c$ and $b c l-x /$ directly by E7 degradations.

However, we need further investigations to prove this hypothesis. Our results and hypothesis are described on Figure 4.
Socs1

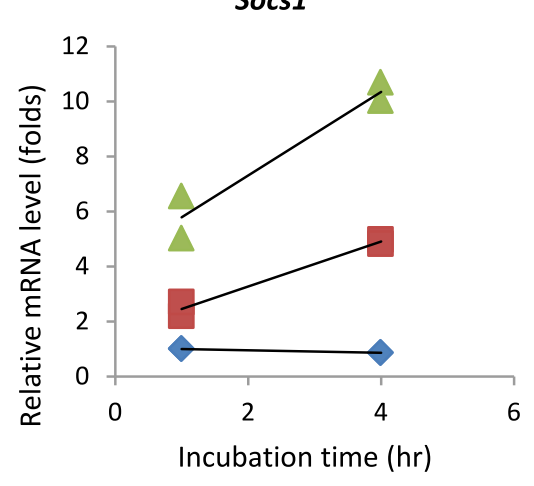

Socs3

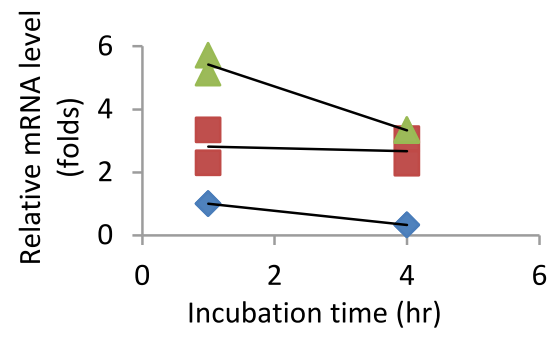

Socs2

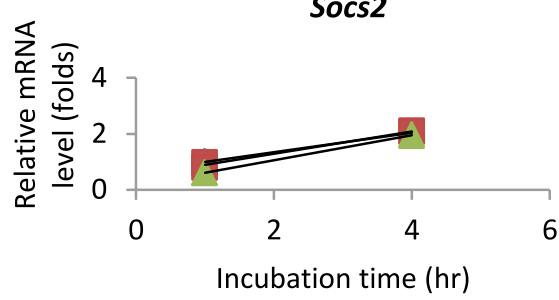

Note:

Socs1 $0 x-y=-0.046 x+1.046\left(R^{2}=0.997\right)$ $20 x-y=0.816 x+1.633\left(R^{2}=0.977\right)$ $30 x-y=1.521 x+4.258\left(R^{2}=0.937\right)$

Socs2 $0 x-y=0.401 x+0.481\left(R^{2}=0.989\right)$ $20 x-y=0.345 x+0.654\left(R^{2}=0.994\right)$ $30 x-y=0.450 x+0.150\left(R^{2}=0.999\right)$

Socs30x $-y=-0.226 x+1.226\left(R^{2}=1\right)$ $20 x-y=-0.050 x+2.867\left(R^{2}=0.926\right)$ $30 x-y=-0.696 x+6.119\left(R^{2}=0.963\right)$

Figure 3. Profil of gene expression pattern of socs 1 , socs 2 and socs 3 responsed to 20 and 30 shots nsPEFs from $1 \mathrm{hr}$ to $4 \mathrm{hr}$ 


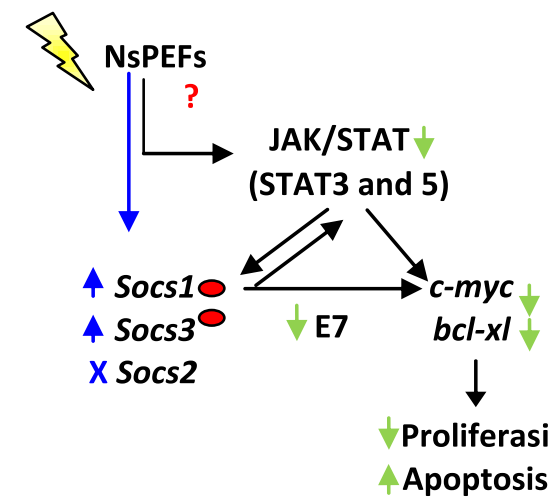

Figure 4 . A schematic diagrams of effect of NsPEFs on socs1, socs 2 and socs 3 gene expressions in HeLa S3 cells.

Note: Blue sign show our result $-(\mathbf{4})=$ gene expressions inductions, $(x)=$ no effect; green sign show our hypothesis - ( / ) = increasing//lecrtasing of expressions; = gene methylation; ?: unO Oown effect)

\section{Possibility Mechanismof NsPEFs to Induce Socs 1 and Socs3} Gene Expressions

This research did not provide any data to explain the mechanism of nsPEFs to inducesocs 1 and socs 3 gene expressions. The high intensity of nsPEFs enter cell and nucleus and induce some endogen genes (14). Possibly, mechanism of nsPEFs to induce socs 1 and socs 3 gene expressions is demethylation.

In general, JAK/STAT signal transduction determines all socs genes as a target of this pathway. However, methylation of socs 1 and socs 3 gene expressions in cervical cancer makes this signal can not raise socs 1 and socs 3 genes. Therefore, we think that methylation process is more important to determine socs 1 and socs 3 gene expressions than JAK/STAT signal transductions. Our results show that nsPEFs only induced socsmethylated genes, socs 1 and socs 3 but not socs 2 . These results suggest that nsPEFs may induce socs 1 and socs 3 by demethylation process. We also propose that nsPEFs does not induce socs 1 and socs 3 by JAK/STAT signal transduction. Our results and hypothesis are describes in Figure 5.

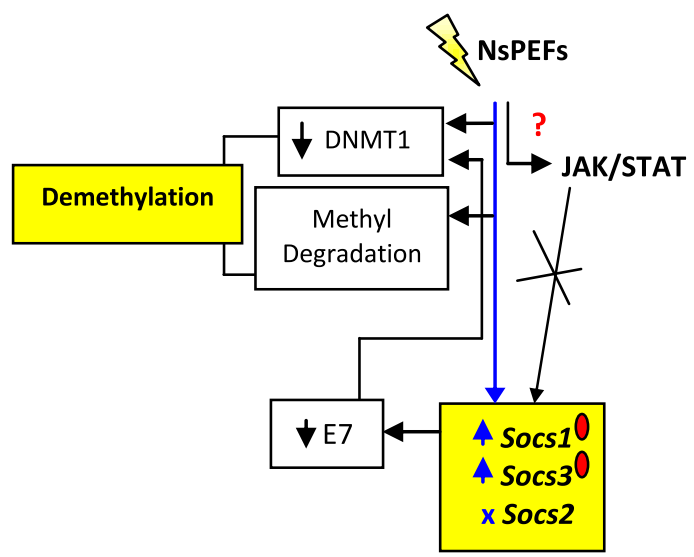

Figure 5. A schematic diagrams of possibility mechanism of NsPEFs to increase socs 1 and socs 3 gene expressions

Note: NsPEFs probably induce socs 1 and socs 3 gene expression by demethylation than JAK/STAT signal transduction
Methylations on promoter of some genes in cervical cancer such as socs 1 and socs 3 are associated with HPV infections and presence of E6 and E7 oncoproteins (38-39). E6 and E7 increase DNA methylatransferase 1 (DNMT1) that catalizes attachment of methyl group to cytosine in CpG Island. Binding E7 to pRb (E7/pRb) cause the release of $E 2 F$, favoring the expression of DNMT1. Binding of E2F to DNMT1 (E7/DNMT1) induced a conformational change in DNMT1 and exposed its DNA binding site and promoting DNA binding (39).

Difference Gene Expression between Socs1 and Socs3 are Determined by Time of NsPEFs Post Exposure and Activity of Each Gene

Based on gene expression pattern analysis, we know that nsPEFs caused different gene expression pattern between socs 1 and socs 3 genes. We can see this different expression in Figure 6.

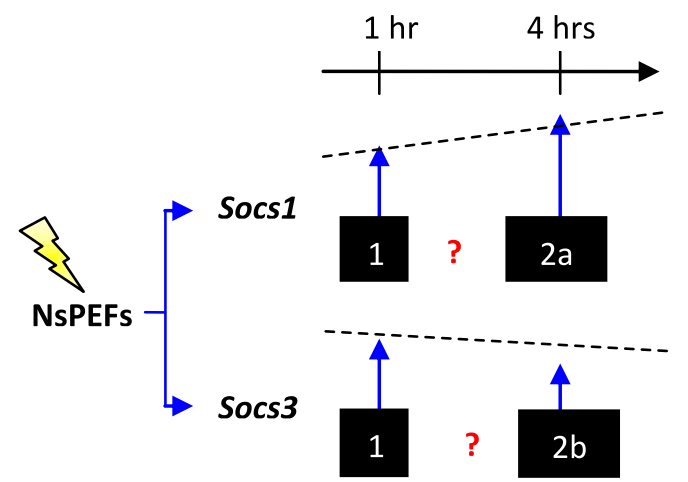

Figure 6. A schematic diagrams of socs1 and socs 3 gene expressions pattern due to nsPEFs exposure.

Note: 1: primary demethylation effect by nsPEFs; 2a: secondary demethylation effect by E7 degradation; $2 \mathrm{~b}$ : decreasing of demethylation effect; ?: The process between $1 \mathrm{hr}$ to $4 \mathrm{hrs}$, it may be associated with negative feedback mechanism of SOCS on JAK/STAT

At $1 \mathrm{hr}$, nsPEFs induced socs 1 and socs 3 gene expressions. Probably, increasing of these gene expressions are induced by directly effect of nsPEFs on socs 1 and socs 3 demethylations that involve decreasing of DNMT1 and methyl degradation. However, there are different gene expressions at $4 \mathrm{hrs}$ between socs 1 and socs 3 . Socs 1 gene expressions increased from $1 \mathrm{hr}$ up to $4 \mathrm{hrs}$, but socs 3 decreased.

The high expressions of socs 1 and socs 3 at $1 \mathrm{hr}$ on time of nsPEFs post exposure probably were caused by directly effect of nsPEFs on degradation of DNMT1 or methyl group (demethylation process). However, different expression on socs 1 and socs 3 probably depend on activity of each gene after socs 1 and socs3 were demethylated. SOCS1 can interact to other signaling pathway NFK $\beta$. Not only by JAK/STAT signal transduction, socs 1 is also induced by NFK $\beta$, but socs3 is not (44).

The high expressions of socs 3 at $1 \mathrm{hr}$ probably caused negative feedback mechanism on JAK/STAT and decreased the target gene such as $c-m y c a n d b c l-x l$. From this mechanism, socs 3 expression also decreased at $4 \mathrm{hrs}$ but still higher that control (cancer cell). Unlike socs3, socs1 gene expression increased at $4 \mathrm{hrs}$. The high expressiob of socs 1 gene probably also caused by induction of NFK $\beta$. In 
cervical cancer, E6 and E7 induce NFK $\beta$ signaling pathway and increase expression of the target genes including cyclin, cdk, bcl-xl, and socs1. However, socs 1 was methylated in HPV infection (39) and cannot decrease 065 subunit (45). Therefore, proliferation increase and apoptosis decrease. Demethylated socs 1 by nsPEFs probably invlove in JAK/STAT and NFK $\beta$. High expression of NFK $\beta$ by E6 and E7 may induce socs1 gene expression without methylated at $4 \mathrm{hrs}$.

SOCS1 has many activities in cervical cancer than SOCS3. SOCS1 is better to decrease proliferation in HeLa S3 than SOCS3 (42). This study also showed that SOCS1 is adaptor of E3 that specific to degrade E7. E7 degradation is important to repress genetic instability in cervical cancer. Low level of E7 is implicated to DNMT1 repression and demethylation some tumor supressor genes such as socs 1 and socs3 (39). Low level of E7 also implicated to inhibition $\mathrm{E} 2 \mathrm{~F}$ and repression of some genes such as c-jun and c-fos (46). SOCS1 can degrade p65 subunit of NFk $\beta$ and decrease $c y c l i n, c d k$, and $b c l-x l(45)$. SOCS1 but not SOCS3 can increase p53 and p21 expressions and implicated to low proliferation and apoptosis induction (47).

According to the discussion, nsPEFs probably directly induce demethylation and activation of $\operatorname{socs} 1$ and socs 3 . However, after activation, the expressions of socs 1 and socs 3 are determined by activity of each gene in cellular mechanism. From this result we know that the higher expression of socs 1 than socs 3 probably determine the

\section{REFERENCES}

1. Chen C, Smye SW, Robinson MP, and Evan JA. Membrane Electroporation Theories: A Review. Medical \& Biological Engineering \& Computing. 2006; 44(1-2): 5-14.

2. Beebe SJ and Schoenbach KH. Nanosecond Pulsed Electric Fields: A New Stimulus to Activate Intracellular Signaling. Journal of Biomedicine and Biotechnology. 2005; 2005(4): 297-300.

3. Deng J, Schoenbach KH, Buescher ES, Hair P, Fox PM, and Beebe SJ. The Effect of Intense Submicrosecond Electrical Pulses on cells. Biophysical Journal. 2003; 84(4): 2709-2714.

4. Crasivo GL, Choe S, Chatterjee P, Chatterjee I, and Vernier PT. Nanosecond Electric Pulses: A Novel Stimulus for Triggering $\mathrm{Ca}^{2+}$ Influx into Chromaffin Cells Via Voltage-Gated $\mathrm{Ca}^{2+}$ Channels. Cellular and Molecular Neurobiology. 2010; 30(8): 1259-1265.

5. Weaver JC, Smith KC, Esser AT, Son RS, and Gowrishanker TR. A Brief Overview of Electroporation Pulse Strength-Duration Space: A Region Where Additional Intracellular Effects are expected. Bioelectrochemistry. 2012; 87: 236-243.

6. Napotnik TB, Wu Y, Gundersen MA, Miklavcic D, and Vernier PT. Nanosecond Electric Pulses Cause Mitochondrial Membrane Permeabilization in Jurkat Cells. Bioelectromagnetic. 2012; 33(3): 257-264.

7. Beebe SJ, Sain NM, and Ren W. Induction of Cell Death Mechanisms and Apoptosis by Nanosecond Pulsed Electric Fields (nsPEFs). Cells. 2013; 2(1): 136-162.

8. Beebe SJ, Chen YJ, Sain NM, Soenbach KH, and Xiao, S. activity of these gene to decrease proliferation in HeLa S3 cell. This result is suitable with the previous research (42).

High Shot Number do not always Associate with High Gene Expressions

Shot number is one of characteristic that also determine the electric fields. Different shot number is proven associated with different cell viability (41) and expression of some gene (13). Our result show that shot number is positively correlates with socs 1 and socs 3 gene expressions. Higher shot number caused higher socs 1 and socs 3 gene expression, but not in socs 2 . We suggest that high shot number do not always assoaciate with high gene expressions.

Finally, we conclude that nsPEFs increase socs 1 and socs 3 but not socs 2 gene expressions. The shot number correlates positively with the socs 1 and socs 3 gene expressions. High shot number do not always correlate with high gene expression. Effect of nsPEFs on socs 1 and socs3 gene expression pattern depends on time of nsPEFs post exposure and type of gene. Because socs 1 and socs 3 have some roles in tumor suppressor, nsPEFs possibly have potentially as anti cancer.

\section{ACKNOWLEDGEMENTS}

We thank JASSO (Japan Student Services Organization) for providing Martina scholarships in IJEP short-term exchange program, Kumamoto University, Japan.

Transient Feature in Nanosecond Pulsed Electric Fields Differentially Modulate Mitochondria and Viability. PLoS One. 2012;7(12): e51349

9. Vernier PT, Sun Y, Mercu L, Salemi S, Craft SM, and Gundersen MA. Calcium Bursts Induced by Nanosecond Electric Pulses. Biochemical and Biophysical Research Communications. 2003; 310(2): 286-295.

10. Morotomi-Yano K, Akiyama H, and Yano K. Nanosecond Pulsed Electric Fields Activate MAPK Pathways in Human Cells. Biochemical and Biophysical Research Communications. 2011; 515(1-2): 99-106.

11. Morotomi-Yano K, Akiyama $\mathrm{H}$, and Yano $\mathrm{K}$. Nanosecond Pulsed Electric Fields Activate AMPActivated Protein Kinase: Implications for CalciumMediated Activation of Cellular Signaling. Biochemical and Biophysical Research Communications. 2012; 428(3): 371-375.

12. Ren Z, Chen X, Cui G, et al. Nanosecond Pulsed Electric Field Inhibits cancer Growth Followed by Alteration in Expression of NF-kB and Wnt/B-catenin Signaling Molecules. PLoS One. 2013; 8(9): e74322.

13. Morotomi-Yano $\mathrm{K}$, Oyadomari S, Akiyama $\mathrm{H}$, and Yano K. Nanosecond Pulsed Electric Act as a Novel Cellular Stress That Induces Translational Suppression Accompanied by elF2a Phosphorylation and 4E-BP1 Dephosphorylation. Experimental Cell Research. 2012; 318: 1733-1744.

14. Beebe SJ, Blackmore PF, White J, Joshi RP, and Schoenbach KH. Nanosecond Pulsed Electric Fields Modulate Cell Function through Intracellular Signal Transduction Mechanisms. Physiological 
Measurement. 2004; 25(4): 1077-1093.

15. Stacey M, Fox P, Buescher S, and Kolb J. Nanosecond Pulsed Electric Field Induced Cytoskeleton, Nuclear Membrane and Telomere Damage Adversely Impact Cell Survical. Bioelectrochemistry. 2011; 82(2): 131134.

16. Beebe SJ, Fox PM, Rec LJ, Willis LK, and Schoenbach $\mathrm{KH}$. Nanosecond, High-Intensity Pulsed Electric Fields Induce Apoptosis in Human Cell. The Journal of the Federation of American Societies for Experimental Biology. 2003; 17(11): 1493-1495.

17. Ren W and Beebe SJ. An Apoptosis Targeted Stimulus with Nanosecond Pulsed Electric Fields (NsPEFs) in E4 Squamous Cell Carcinoma. Apoptosis. 2011; 16(4): 382-393.

18. Ford WE, Ren W, Blackmore PF, Schoenback KH, and Beebe SJ. Nanosecond Pulsed Electric Fields Stimulate Apoptosis without Release of Pro-Apoptototic Factors from Mitochondria in B16f10 Melanoma. Archieves of Bioechemistry and Biophysics. 2010; 497(1-2): 82-89.

19. Stacey M, Stickley J, Fox $P$, et al. Differential Effects in Cells Exposed to Ultra-Short, High Intensity Electric Fields: Cell Survival, DNA Damage, and Cell Cycle Analysis. Mutation Research. 2003; 542(1-2): 65-75.

20. Nagahama M, Shimomura N, Nakagawa A, Teranishi K, Uto $\mathrm{Y}$, and Hori H. In Vivo Experimental Study of Nanosecond Pulsed Electric Field Effects on Solid Tumors. IEEE Transactions on Dielectrics and Electrical Insulation. 2013; 20(4): 1266-1272.
21. Nuccitelli R, Pliquett $U$, Chen $X$, et al. Nanosecond Pulsed Electric Fields Cause Melanomas to SelfDestruct. Biochemical and Biophysical Research Communications. 2006; 343(2): 351-360.

22. Wu S, Wang Y, Guo J, Chen Q, Zhang J, and Fang J. Nanosecond Pulsed Electric fields as a Novel Drug Free Therapy for Breast Cancer: An In Vivo Study. Cancer Letters. 2014; 343(2): 268-274.

23. Beebe SJ. Bioelectrics in Basic Science and Medicine: Impact of Electric Fields on Cellular Structures and Functions. Nanomedicine and Nanotechnology. 2013; 4(2): 1-8.

24. Rawlings JS, Rosler KM, and Horrison DA. The JAK/STAT Signaling Pathway. Journal of Cell Science. 2004; 117: 1281-1283.

25. Elliott J, Hookham MB, and Johnston JA. The Suppressors of Cytokine Signalling E3 Ligases Behaves as Tumor Suppressors. Biochemical Society Transactions. 2008; 36(Pt3): 464-468.

26. Weniger MA, Melzner I, Menz CK, et al. Mutations of the Tumor Suppressor Gene SOCS1 in Classical Hodgkin Lymphoma are Frequent and Associated with Nuclear Phospho-STAT5 Accumulation. Oncogene. 2006; 25(18): 2679-2684.

27. Nagai H, Naka T, Terada Y, et al. Hypermethylation Associated with Inactivation of the SOCS-1 Gene, a JAK/STAT Inhibitor, in Human Hepatoblastomas. Journal of Human Genetics. 2003; 48(2): 65-69. 